Arq. Bras. Med. Vet. Zootec., v.69, n.2, p.333-339, 2017

\title{
Intraventricular pneumocephalus associated with nasocephalic necrosis in a puppy: a case report
}

\author{
[Pneumoencéfalo intraventricular associado à área de necrose nasoencefálica em \\ filhote canino: relato de caso] \\ J.O. Sena ${ }^{1}$, K.C.R. Costa $^{1}$, P.M. Costa ${ }^{1}$, F.G. Miranda ${ }^{1}$, J.F. Silva ${ }^{2}$, R.C.S. Tôrres ${ }^{1 *}$ \\ ${ }^{1}$ Aluna de pós-graduação - Escola de Veterinária - Universidade Federal de Minas Gerais - Belo Horizonte, MG \\ ${ }^{2}$ Escola de Veterinária - Universidade Federal de Minas Gerais- Belo Horizonte, MG
}

\begin{abstract}
Pneumocephalus is defined as the presence of air in any of the intracranial compartments. Its most frequent causes are trauma and cranial surgery. Clinical signs occur as a result of increased intracranial pressure and vary with the location and extent of the lesion. A case involving a seven-month-old female Saint Bernard, who suffered cranial trauma caused by a bite to the face at ten days of age and had presented with seizures and localized pain four months previously is reported. A computed tomography scan of the skull revealed a nasocephalic mass with low contrast enhancement, bone lysis, and hypodensity (-940 Hounsfield units) of the lateral and third ventricles, indicating intraventricular pneumocephalus. During surgery, a fragment of the mass was collected for histopathological examination, which demonstrated the presence of multifocal areas of necrosis. The computed tomography (CT) is a reliable method for the characterization of intracranial lesions and diagnosis of pneumocephalus, whose occurrence must be considered in pathological processes in which there is increased intracranial pressure and in patients undergoing certain surgical procedures and anesthetic specific, and CT is indicated as a monitoring tool for these patients.
\end{abstract}

Keywords: dog, computed tomography, intracerebral aerocele, pneumoventricle

\section{RESUMO}

Pneumoencéfalo é definido como a presença de gás em quaisquer dos compartimentos intracranianos $e$ possui como causas mais frequentes o traumatismo e cirurgias cranianas. Os sinais clínicos ocorrem como consequência do aumento de pressão intracraniana e variam conforme o local e a extensão da lesão. Relata-se o caso de uma cadela de sete meses de idade, da raça São Bernardo, que sofreu trauma por mordedura em face, quatro meses antes, apresentando crises convulsivas e sensibilidade dolorosa local desde então. O exame tomográfico do crânio revelou massa nasoencefálica com baixa captação de contraste, lise óssea e hipodensidade $(-940 \mathrm{HU})$ dos ventrículos laterais e terceiro ventrículo encefálico, caracterizando pneumoencéfalo intraventricular. Foi realizada intervenção cirúrgica e coleta de fragmento da massa para exame histopatológico, que demonstrou existência de necrose multifocal. $O$ exame de tomografia computadorizada (TC) é um método confiável para a caracterização de lesões intracranianas e diagnóstico de pneumoencéfalo, cuja ocorrência deve ser considerada em processos patológicos nos quais há aumento da pressão intracraniana e em pacientes submetidos a alguns procedimentos cirúrgicos e anestésicos específicos, sendo a TC indicada como ferramenta de monitoramento desses pacientes.

Palavras-chave: cão, tomografia computadorizada, aerocele intracerebral, pneumoventrículo

Recebido em 4 de dezembro de 2015

Aceito em 11 de outubro de 2016

*Autor para correspondência (corresponding author)

E-mail: rtorres@vet.ufmg.br 


\section{INTRODUCTION}

Pneumocephalus, also known as intracerebral aerocele or pneumatocele, is defined as the presence of air in any of the intracranial compartments (ventricular, parenchymal, subarachnoid, or subdural compartments). It usually occurs after cranial trauma or neurosurgical procedures, although it may also result from gas produced by bacteria during infection, mucoceles, congenital neurenteric cysts, and dural defects (Schirmer et al., 2010; Pereira et al., 2011). The main clinical signs of pneumocephalus in humans occur because of increased intracranial pressure and are characterized by cephalea, epileptic seizures, reduced level of consciousness, nausea, emesis, dizziness, and paresis (Alves et al., 2012).

Previous reports of pneumocephalus in veterinary medicine involve animals that have suffered from trauma or undergone surgical procedures (Garosi et al., 2002; Garosi et al., 2005; Fletcher et al., 2006; Haley and Abramson, 2009). Here, a case of pneumocephalus that developed in a seven-month-old Saint Bernard dog and was associated with areas of intranasal necrosis invading the frontal lobes and olfactory bulbs is described. CT of the brain showed that the lateral and third ventricles were filled with air, indicating intraventricular pneumocephalus. This may have been caused by a fistula resulting from bone lysis.

\section{CASE STUDY}

At ten days of age, a female Saint Bernard puppy was bitten on the face. Three months later, the dog presented with epileptic seizures, difficulty when chewing food and swallowing liquids, and behavioral changes (anxiety and aggression). During the initial consultation, unilateral purulent nasal discharge was identified on the right side. Sulfametoxazol drugs (30 mg $/ \mathrm{kg}$, BID) and phenobarbital $(3 \mathrm{mg} / \mathrm{kg}, \quad$ BID) were administered immediately and the dog was subsequently referred to a neurologist.

Four days after the start of the aforementioned therapy, neurological examination revealed hyperesthesia, reduced pelvic limb reflexes, diminished hearing, anxiety, reduced gag and swallowing reflexes, and trembling of the thoracic limbs, which are typical signs of lesions in the prosencephalon and cerebellum. Moreover, facial bone deviation was observed on the right side. Nasal symptoms improved after treatment with sulfametoxazol drugs.

CT of the nasal cavity and brain was conducted to determine the cause of the symptoms. CT of the nasal cavity (Figure 1) revealed a bilateral intranasal mass with a density of 20-40 Hounsfield units (HU), which was poorly vascularized and not well defined. Osteolysis, nasal septal deviation, and deformity of the nasal bones and cribriform plate were evident. The left sphenoid paranasal sinus and right maxillary recess were also affected by osteolysis. The iodinated contrast medium iohexol was administered at a dose of $2 \mathrm{~mL} / \mathrm{kg}$, IV. The intranasal mass only presented low signal intensity in the peripheral region. During the examination, fine-needle aspiration (FNA) was performed, guided by CT identified structure (Figure 2). Cytological assessment of material collected by FNA was carried out - slides were stained by quick Romanovsky-type stain (Panótico Rápido LB $囚$ ), like carried out in the case described by Pereira et al, 2013 -, as well as Culture and antibiogram of a swab of intranasal discharge, using Mueller-Hinton agar for disk diffusion susceptibility test, recommended by Clinical and Laboratory Standards InstituteC (Performance..., 2012).

Bacterial culture and antibiogram of the nasal discharge showed moderate growth of Staphylococcus intermedius. Cytological assessment was inconclusive, showing an intense concentration of blood cells, moderate vascularization, and the presence of epithelial cells without malignant atypia, in addition to some negative structures indicating hyphae. Ideally, a fungal culture should have been conducted; however, there was not enough material to do so.

The dog continued to receive phenobarbital and was also started on carprofen $(2 \mathrm{mg} / \mathrm{kg}$, BID PO) and clindamycin chlorhydrate $(15 \mathrm{mg} / \mathrm{kg}$, BID $\mathrm{PO})$, which is an antibiotic that inhibits bacterial protein synthesis. Staphylococcus intermedius was sensitive to clindamycin chlorhydrate on the antibiogram performed. 


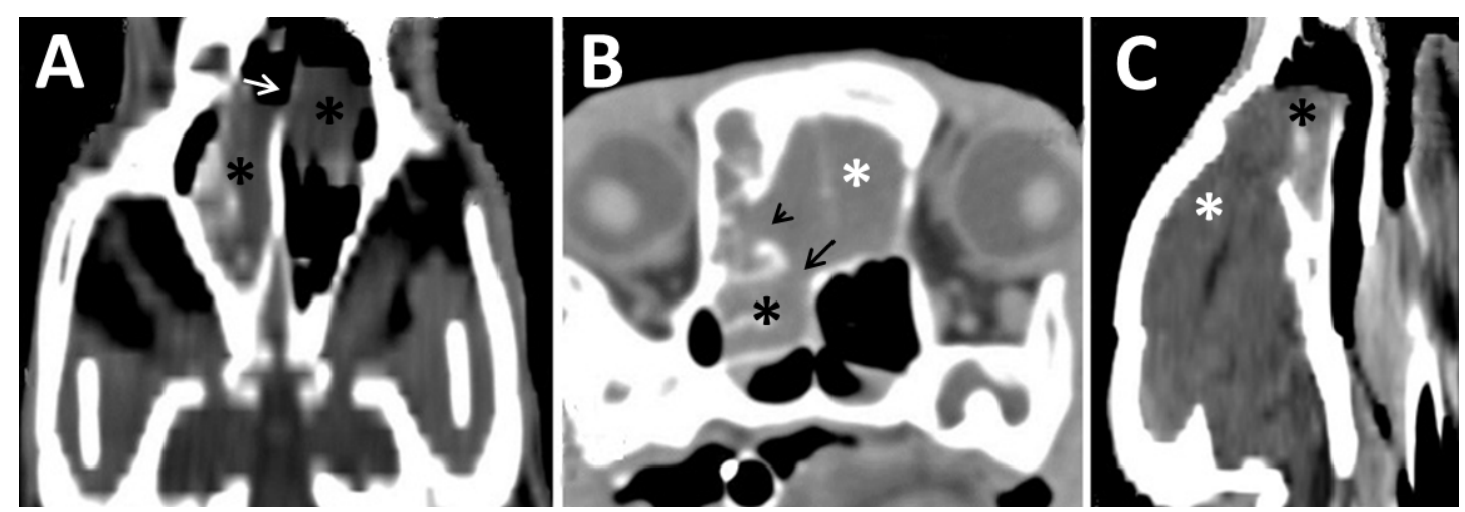

Figure 1. CT scans of the nasal cavity of a three-month-old Saint Bernard dog presenting with a chronic nasal disorder and seizures. A. Dorsal reconstruction of the nasal cavity showing the presence of a bilateral mass (asterisk) in the nasal cavity and lysis of the nasal septum (arrow). B. Cross-sectional image of the nasal cavity showing the mass (asterisk) invading the brain (white asterisk) and lysis of the frontal bone (arrow head) and cribriform plate (arrow). C. Longitudinal reconstruction showing the nasocephalic mass (asterisk: mass; white asterisk: brain).

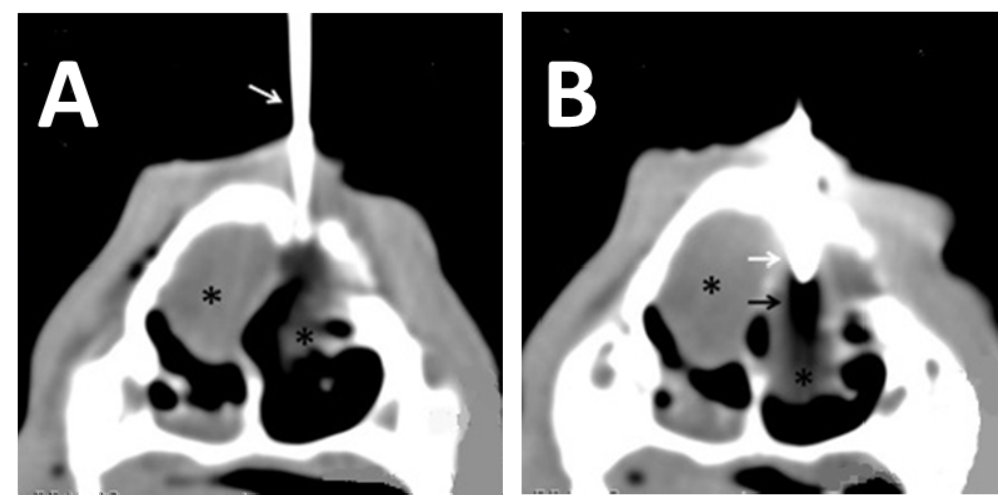

Figure 2. Cross-sections of fine-needle aspiration guided by CT scan. A: shows the needle as a linear hyperdense image (white arrow) positioned inside the mass (asterisk). B: The metal that makes up the needle (white arrow) produces an artifact known as strike (black arrow), characterized by an blackened area visualized close to high-density materials (asterisk $=$ mass).

At seven months of age, the dog showed an improvement in her aggressive behavior and the number of seizures she suffered; however, facial pain could still be detected. When the dog was clinically stable, a second tomographic examination was performed in order to assess the progress of the lesion and determine the best clinical and/or surgical treatment, taking into account potential prosencephalic compression and close contact with the nervous tissue.

This second CT examination of the nasal cavity and brain revealed the presence of an intranasal mass starting near the upper right canine tooth, with a density of 30-40 HU. The mass was seen to be invading the skull, adjacent to the frontal lobes and olfactory bulbs (Figure 3). It was poorly delimited, with a size of approximately $2.9 \mathrm{~cm}$ (width) $\times 2.9 \mathrm{~cm}$ (height). Iodinated contrast medium (iohexol) was administered at a dose of $2 \mathrm{~mL} / \mathrm{kg}$, IV. Although the mass still showed poor contrast enhancement, the lateral, i.e., left and right, and third ventricles appeared hypodense (-940 HU), indicating the occurrence of pneumocephalus or, more specifically, intraventricular pneumocephalus. No intraluminal fluid was detected (Figures 4 and 5). 

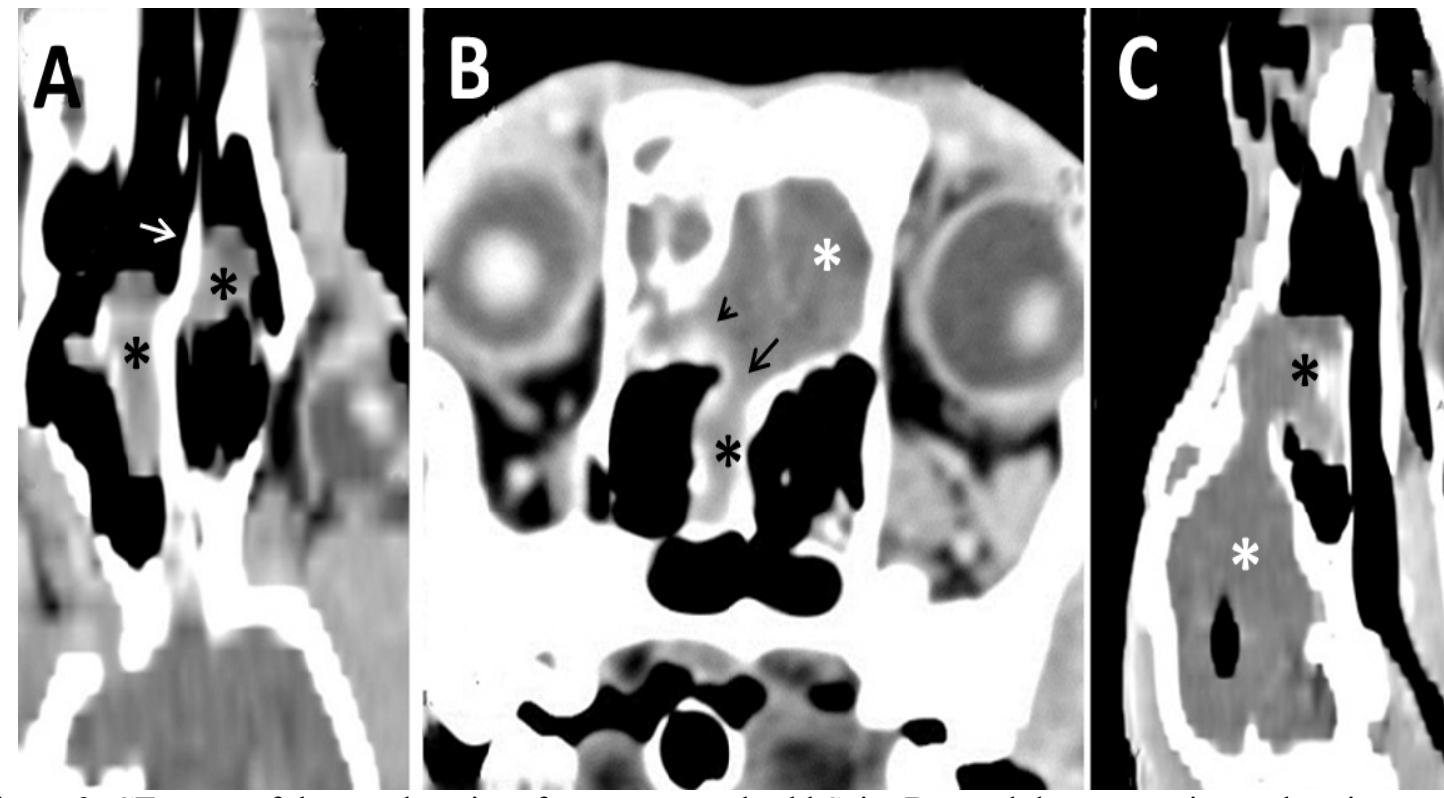

Figure 3. CT scans of the nasal cavity of a seven-month-old Saint Bernard dog presenting a chronic nasal disorder and seizures. A: Dorsal reconstruction of the nasal cavity showing a bilateral mass (asterisk) and a lysis of the nasal septum (white arrow). B: Cross-sectional image of the nasal cavity showing the mass (black asterisk) invading the brain (white asterisk), the lysis of the frontal bone (arrow head) and the lysis cribriform plate (arrow). C: Longitudinal reconstruction showing the nasocephalic mass. It is possible to see gas in the lateral ventricle (black asterisk: mass; white asterisk: brain).
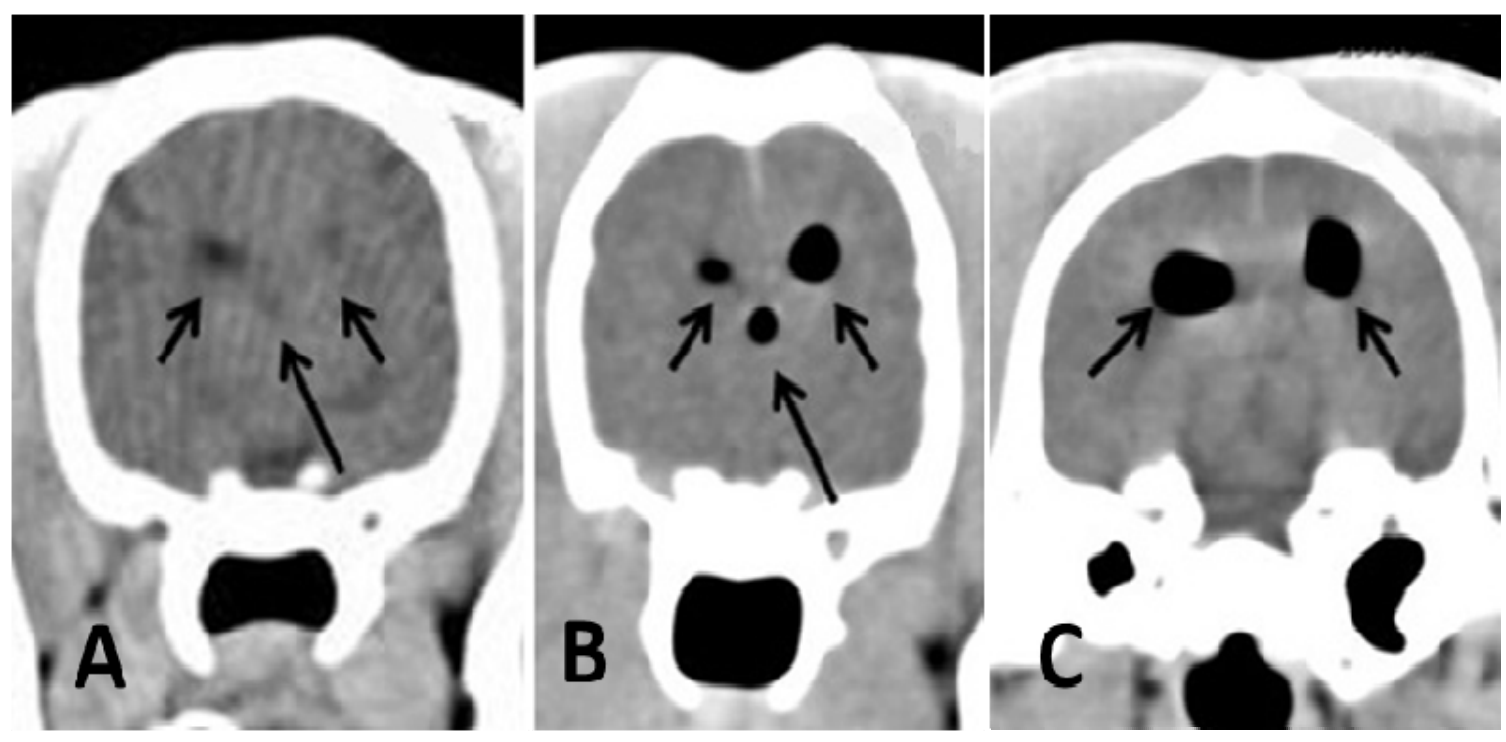

Figure 4. Intraventricular pneumocephalus in a Saint Bernard dog presenting with neurological symptoms: comparison between tomography examinations at 3 months (A) and 7 months (B and C) of age. A. Cross-sectional image of the brain showing the lateral (short arrows) and third (long arrow) ventricles, which were more visible than normal but still filled with fluid. B and C. Cross-sectional images of the brain showing the lateral and third ventricles dilated and filled with air, as typically occurs in intraventricular pneumocephalus. 


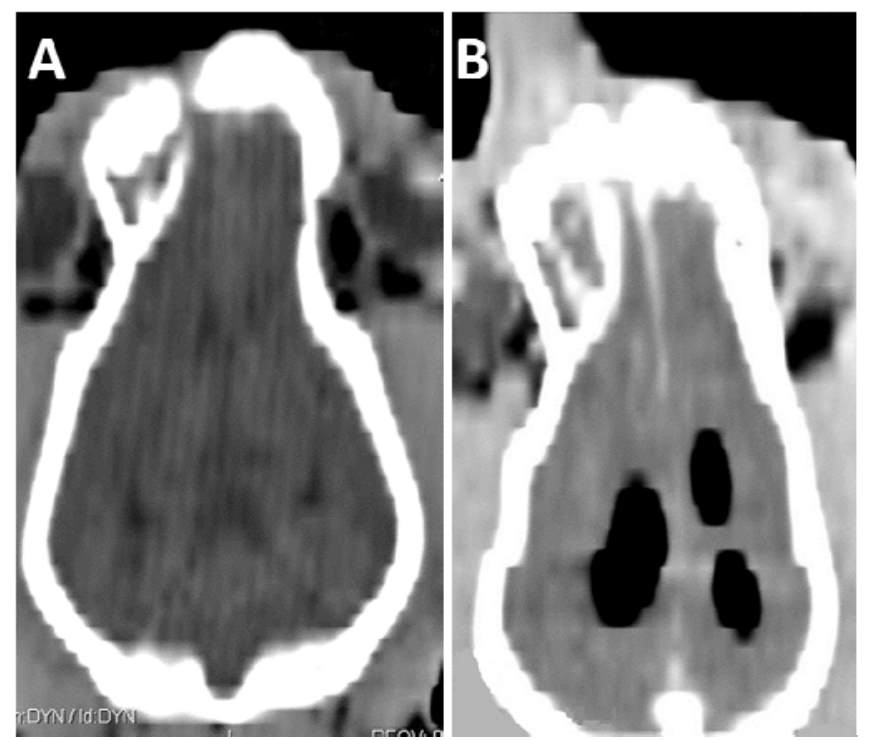

Figure 5. Intraventricular pneumocephalus in a Saint Bernard dog presenting neurological symptoms. Comparison between tomography examinations at 3 months (A) and 7 months (B) of age. Brain dorsal reconstruction showing the lateral ventricles normal (A) and filled by gas $(\mathrm{B})$.

The dog underwent surgery to remove the intranasal tissue. The frontal lobes of the brain appeared friable and grey in color. Histopathological analysis of a fragment of the mass revealed the presence of discrete multifocal areas of necrosis associated with moderate fibroplasia, hemorrhage, and lymphocytic inflammatory infiltrates. No bacteria, fungi, or protozoans were observed in the fragment analyzed. The patient died around five hours after the procedure and its owners did not allow a necropsy.

\section{DISCUSSION}

Many characteristics indicated infections: bite trauma, low contrast enhancement in the $\mathrm{CT}$ and satisfactory response to antibiotic treatment. Nonetheless, the histopathological analysis did not reveal the presence of bacterial agents in the sample collected. Even though a fungal culture was not performed, it is probable that fungal infection was not the principal cause of the lesion observed, for the same reasons already cited, but a chronic inflammation.

It is likely that the intranasal bacterial infection detected was secondary and probably due to a bacterial contaminant in the culture plate, since the bacteria isolated was Staphylococcus intermedius, which belongs to the nasal microbiota. According to Windsor and Johnson (2006), primary infections of the nasal cavity are rare, although secondary infections are very common in dogs with chronic nasal disease. Nasal discharge cultures may therefore present mixed bacterial growth of nasal microbiota such as Staphylococcus, Streptococcus, Escherichia coli, Proteus, Pasteurella, Corynebacterium, Bordetella, and Pseudomonas, which is in line with our hypothesis.

CT of the skull allows quick and accurate identification of an extensive variety of intracranial lesions. In many instances, this examination provides a definitive diagnosis whereas, in other cases, CT scans provide complementary information, guiding the choice of neurological, clinical, or surgical treatment (Osborn et al., 1978).

Intraventricular pneumocephalus observed by CT can occur as a result of communication between the ventricles and nasal cavity after trauma, as seen in $75 \%$ of the human cases reported (Pereira et al., 2011). Traumatic pneumocephalus in humans tends to regress spontaneously and is normally absorbed after two days; however, in some patients, it may persist for longer than five days. If it does not resolve within this time, surgical removal is recommended (Alves et al., 2012). In the current case, no changes 
characteristic of intraventricular pneumocephalus were detected during the first CT examination, even though CT was carried out three months after the initial trauma and in the presence of a nasocephalic lesion.

The presence of air in the ventricles may be a result of gas released by bacterial metabolism (Tanaka et al., 1989). In the current case, this hypothesis was discarded because bacterial growth was not observed in the material collected, with the exclusion of nasal microbiota.

Pneumocephalus may also occur spontaneously, as a result of fistula formation in areas of prosencephalic necrosis. However, this cannot always be visualized by $\mathrm{CT}$, as in cases of primary encephalic lesions, the physical brain barriers are disrupted (Pereira et al., 2011). It is likely that this scenario occurred in the current case.

The most likely hypothesis is that the pneumocephalus was incidentally found and the presence of gas quantity in the ventricles has not been able to lead clinical signs, but the presence of this gas indicated the bone lysis was happening.

As the extent of the lesion was significant and no signs of regression were observed with medical treatment alone, surgical intervention was required in the present case. CT monitoring immediately after surgery must be prioritized, since complications associated with the occurrence of pneumocephalus should be expected (Garosi et al., 2002).

There are few pneumocephalus reports in veterinary medicine, none with the features observed in this case, in which the lesion probably resulted from fistula originated in the ancient trauma site. Its occurrence should also be considered in pathological processes in which there is increased intracranial pressure, additional craniotomy complication, rhinotomy and, as reported in humans, epidural anesthetic procedures. In any of these situations, monitoring is recommended by $\mathrm{CT}$, in order to define the cause of intracranial hypertension or as postsurgical monitoring in concerning the appearance of iatrogenic pneumocephalus.

\section{CONCLUSIONS}

CT is a reliable method for the characterization of intracranial lesions and diagnosis of pneumocephalus, as it allows the identification and precise localization of this type of lesion. In the case reported here, intraventricular pneumocephalus was discovered accidentally, suggesting the potential occurrence of pneumocephalus in intracranial lesions. This condition represents an additional complication of a pathology in which increased intracranial pressure requires $\mathrm{CT}$ monitoring to determine treatment strategies.

\section{ACKNOWLEDGEMENTS}

Office of the Dean of Research at the Universidade Federal de Minas Gerais.

\section{REFERENCES}

ALVES, F.A.G.; FREIRE, F.S.; MARCOLINO, P.R.B. et al. Pneumoencéfalo associado a trauma de face: relato de caso. Rev. Cirurg. Traumat. Buco-maxilo-fac., v.12, p.69-72, 2012.

FLECHER, D.J.; SNYDER, J.M.; CHIU, A.G.; VITE, C.H. Ventricular pneumocephalus and septic meningoencephalitis secondary to dorsal rhinotomy and nasal polypectomy in a dog. $J$. Am. Vet. Med. Assoc., v.229, p.240-245, 2006.

GAROSI, L.S.; McCONNELL, F.J.; LUJAN, A. What is your diagnosis? J. Am. Vet. Med. Assoc., v.226, p.1057-1058, 2005.

GAROSI, L.S.; PENDERIS, J.; BREARLEY, M.J. et al. Intraventricular tension pneumocephalus as a complication of transfrontal craniectomy: a case report. Vet. Surg., v.31, p.226-231, 2002.

HALEY, A.; ABRAMSON, C. Traumatic pneumocephalus in a dog. J. Am. Vet. Med. Assoc., v.234, p.1295-1298, 2009.

OSBORN, A.G.; DAINES, J.H.; WING, S.D.; ANDERSON, R.E. Intracranial air on computerized tomography. J. Neurosurg., v.48, p.355-359, 1978. 
Intraventricular pneumocephalus...

PEREIRA, J.S.; PONTES, F.T.G.; ANTONUCCI, A.T. et al. Pneumoencéfalo espontâneo hipertensivo secundário a osteoma de seio frontal: relato de caso e revisão da literatura. $J$. Bras. Neurcir., v.22, p.48-51, 2011.

PEREIRA, M.F.; SANTOS, B.M.; SILVA V.C.L. et al. Aspectos clínicos e anatomopatológicos da criptococose nasal com disseminação sistêmica em cão: relato de caso. Rev. Med. Vet., v.7, p.7-15, 2013.

PERFORMANCE standards for antimicrobial disk susceptibility tests. M02-A11. Approved Standard. 11.ed. Wayne, PA: CLSI, 2012. v.32, n.1.
SCHIRMER, C.M.; HEILMAN, C.B.; BHADWAJ, A. Pneumocephalus: case illustrations and review. Neurocrit. Care Soc., v.13, p.152-158, 2010.

TANAKA, T.; TAKAGI, D.; TAKEYAMA, N.; KITAZAWA, Y. "Spontaneous" pneumocephalus associated with aerobic bacteremia. Clinic. Imaging, v.13, p.134-139, 1989.

WINDSOR, R.C.; JOHNSON, L.R. Canine chronic inflammatory rhinitis. Clinic. Tech. Small Anim. Pract., v.21, p.76-81, 2006. 